\title{
FLUORIDE INTAKE FROM DRINKING WATER AND DENTIFRICE BY CHILDREN LIVING IN A TROPICAL AREA OF BRAZIL
}

\author{
INGESTÃO DE FLÚOR PELA ÁGUA E CREME DENTAL POR CRIANÇAS RESIDENTES DE \\ UMA ÁREA DE CLIMA TROPICAL DO BRASIL
}

Leila Maria F. OMENA ${ }^{1}$, Milton F. de A. SILVA², Cleone Calheiros PINHEIRO ${ }^{1}$, Jairo C. CAVALCANTE ${ }^{4}$, Fábio Correia SAMPAIO ${ }^{5}$

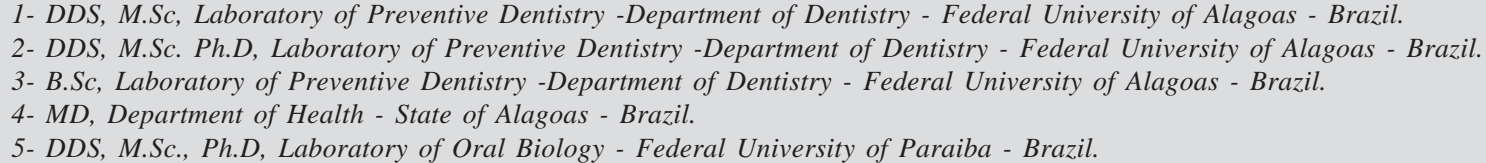

\begin{abstract}
O

bjective: To assess fluoride (F-) intake from water and toothpaste by children aged 18 to 36 months and to monitor the Fconcentrations in the drinking water system in a tropical city of Brazil. Methods: Children (n=58) aged 18-36 months, all lifetime residents of Penedo, state of Alagoas, Brazil, participated in this study. Water $\mathrm{F}^{-}$analyses were carried out in 7 different occasions at least a week apart. For 2 days all the water drunk by each child was accounted for. Fluoride intake from water for each child was estimated using the mean $\mathrm{F}^{-}$concentration of water in 7 different occasions. Fluoride intake from toothpaste was estimated by subtracting the recovered post-brushing $\mathrm{F}^{-}$from the original amount placed in the toothbrush. The $\mathrm{F}^{-}$intake from water and toothpaste was estimated by dividing the total amount of $\mathrm{F}^{-}$ingested by the weight of each child. Results: The mean $\mathrm{F}^{-}$concentration in the drinking water was $0.94 \mathrm{ppm}$ (mean range $0.78-1.1 \mathrm{ppm}$ ), which is above the $0.7 \mathrm{ppm}$ recommended for this area of Brazil. Mean total $\mathrm{F}^{-}$intake from water and toothpaste was $0.128 \mathrm{mg} \mathrm{F}^{-} / \mathrm{Kg}$ Body Weight/day. The daily means of $\mathrm{F}^{-}$ intake from water and toothpaste were 0.021 and $0.107 \mathrm{mg} \mathrm{F} / \mathrm{Kg}$ Body Weight, respectively. Ninety six percent of children showed F- intake above $0.07 \mathrm{mg} \mathrm{F} / \mathrm{Kg}$ Body Weight/day. Conclusions: Children in Penedo are at risk for developing dental fluorosis due to high $\mathrm{F}^{-}$intake from fluoridated toothpastes. Water fluoridation showed low contribution to the total $\mathrm{F}^{-}$intake. However, high water F- concentrations in the water indicate the need of surveillance of the artificial water fluoridation system. Uniterms: Fluoride; Fluoridation; Toothpastes.
\end{abstract}

\section{RESUMO}

bjetivos: determinar a ingestão de flúor (F-) pela água e creme dental em crianças de 18 a 36 meses de idade que moram em uma cidade de clima tropical no Brasil e monitorar as concentrações de F- no sistema de água potável. Materiais métodos: participaram deste estudo crianças ( $\mathrm{n}=58), 18-36$ meses, todas residentes vitalícias de Penedo (Alagoas), Brasil. As análises de F- em amostras de água foram realizadas em 7 ocasiões diferentes em semanas separadas. Durante 2 dias toda a água bebida por cada criança foi considerada. A ingestão de fluoreto para cada criança foi calculada pela média de flúor na água nas 7 ocasiões diferentes. A ingestão de F- pelo creme dental foi calculada subtraindo a saliva recuperada do expectorado pela quantidade de $\mathrm{F}^{-}$colocada na escova dental. A ingestão de $\mathrm{F}^{-}$de água e pasta de dentes foi calculada dividindo a quantia de $\mathrm{F}$ ingerida pelo peso de cada criança. Resultados: A concentração média de F- em água potável foi de 0,94 ppm (variando de 0.78-1.12 ppm) estando acima do recomendado para esta área do Brasil que é de 0,7 ppm. A ingestão de F- total (água + creme dental) foi de 0,128 mg de F/Kg peso/dia. As médias diárias de ingestão de F- pela água e creme dental foram de 0,021 e 0,107 mg F-/Kg de peso corporal dia, respectivamente. Noventa que seis por cento das crianças demonstraram ingestão de $\mathrm{F}^{-}$superior a $0,07 \mathrm{mg}$ de $\mathrm{F}^{-}$ /Kg peso/dia. Conclusões: crianças em Penedo estão sob risco de desenvolver fluorose dental devido a elevada ingestão de F- pelo creme dental fluoretado. Adição de flúor à água de água mostrou baixa contribuição ao flúor total ingerido. Porém, altas concentrações de F- na água indicam a necessidade de vigilância do sistema de fluoretação artificial das águas.

Unitermos: Flúor; Fluoretação; Creme dental. 


\section{INTRODUCTION}

Fluoridated toothpastes have been regarded as one of the most important factors responsible for the decline of caries incidence in the western world during the last decades $^{5,16}$. Fluoride $\left(\mathrm{F}^{-}\right)$has also been implicated with an increase in dental fluorosis ${ }^{23,6,17}$. There are compelling evidences that the use of fluoridated toothpaste before six years of age is a risk indicator for dental fluorosis ${ }^{17,7}$. In order to avoid the side effect of fluorosis, the amount of ingested fluoride should not exceed $0.07 \mathrm{mg} \mathrm{F} / \mathrm{Kg}$ body weight/day ${ }^{3,14}$. The critical period for dental fluorosis in permanent maxillary incisors appears to be from 15 to 24 months of age for boys and 21 to 30 months of age for girls ${ }^{7,13}$

Two previous Brazilian studies performed in the South Region of Brazil demonstrated a total $\mathrm{F}$ intake in children of $0.09 \mathrm{mg} \mathrm{F} / \mathrm{Kg}$ body weight/day with $55 \%$ attributed to fluoridated toothpastes ${ }^{15}$ and $0.13 \mathrm{mg} \mathrm{F}$-/Kg body weight/ day with $80 \%$ attributed to fluoridated toothpastes ${ }^{1}$. So far, no data are available about the fluoride intake by children from the Northeast Region of Brazil, where industrial food is less consumed and utilization of fluoridated toothpastes may differ.

The purpose of this study was twofold: a) to assess the fluoride intake by children aged 18 to 36 months living in a tropical area of Brazil from fluoridated water and toothpaste and $\mathrm{b}$ ) to assess the $\mathrm{F}^{-}$concentration in the drinking water of the city of Penedo.

\section{MATERIALAND METHODS}

\section{Area under study}

The city of Penedo, with approximately 60,000 inhabitants, is one of the few cities of the Northeast region of Brazil with artificial water fluoridation. Fluoridation has been active since 1989. Penedo is localized at the northern margin of the São Francisco river, from where the water is collected and transferred to a water treatment plant where fluoride is added. The mean annual temperature is above $24^{\circ} \mathrm{C}^{12}$. About $50 \%$ of the population survives with an annual income of US\$330.00 and 4.2\% have no income ${ }^{11}$. The DMFT of the region is around 3.5 for non-fluoridated communities and 1.7 for communities like Penedo ${ }^{2}$. A dental caries preventive program in nurseries and schools is available. The preventive program includes toothbrushing with fluoridated toothpaste twice a day in the nursery and mouthrinse with $0.2 \% \mathrm{NaF}$ for school children older than 6 years of age.

\section{Ethical consent and sample}

The Institutional Review Board of the Federal University of Alagoas, Brazil, granted permission for the study. Only children (aged 18-36 months) whose parents signed the consent letter and provided full cooperation regarding sample collection and answered a questionnaire participated in this study. Fifty-eight children (28 male and 30 female) were eligible. These children were born and lifetime residents in Penedo and used the communal fluoridated water since birth; 32 were enrolled in the municipal nurseries, where they stayed all day, and 26 had to be followed at home.

\section{Oral hygiene habits}

Parents filled a questionnaire to provide data about the frequency that their child brushes his/her teeth, at what age they started toothbrushing, if they rinse their mouths after toothbrushing and if they have the habit of swallowing toothpaste. Additionally, one of the authors (LMFO) observed and registered the events during each child's toothbrushing procedure.

\section{Water fluoride analysis}

Drinking water samples were collected on seven different days. These 7 days of water collection were at least a week apart from each other. On the scheduled day, water samples were collected from 10 different locations across Penedo and analized for $\mathrm{F}^{-}$concentration.

After diluting each sample $(1: 1 \mathrm{v} / \mathrm{v})$ with TISAB II, fluoride analysis was done in duplicate, using a specific ion electrode (combined F- electrode 9609, Orion Research Inc., USA) coupled to a pH/MV meter (Procyon Research Inc., Brazil). Fluoride standards ranged from $0.1-10$ ppm F-.

The $\mathrm{F}^{-}$values in $\mathrm{ppm}$ were averaged to produce the fluoride concentration of the day.

\section{Fluoride analysis in fluoridated toothpastes}

A duplicate sample, $100 \mathrm{mg}$, of the dentifrices used by the children was analyzed for fluoride. Each sample was homogenized with $10 \mathrm{~mL}$ of distilled deionized water. Then, $0.5 \mathrm{~mL}$ of $2 \mathrm{M}$ HCL were added to $0.5 \mathrm{~mL}$ of the dentifrice solution. The former was incubated at $45^{\circ} \mathrm{C}$ under constant agitation for 2 hours. After this time the mixture was neutralized with $1.0 \mathrm{~mL}$ of $1 \mathrm{M} \mathrm{NaOH}$ and $2 \mathrm{~mL}$ of TISAB II were added. The fluoride concentration of each dentifrice sample was assessed using a specific ion electrode (combined F- electrode 96-09 Orion Res. Inc., USA) coupled to a $\mathrm{pH} / \mathrm{MV}$ meter (Procyon Research Inc., Brazil). Standards ranged from 4 to $64 \mathrm{ppm} \mathrm{F}^{-}$.

\section{Fluoride intake from drinking water}

All the water ingested by each child during 2 days was accounted for. At the nurseries, water was weighed at each time a child asked for it. For those who were followed at home, a duplicate sample was collected and stored to be weighed later at the laboratory. The fluoride ingestion from water was calculated by multiplying the quantity of ingested water by the mean fluoride in the water calculated from the 7 days water collection samples. Results are expressed as $\mathrm{mg} \mathrm{F}$-/Kg body weight/day.

\section{Fluoride intake from fluoridated toothpastes}

The Rojas-Sanchez protocol was followed ${ }^{21}$. In brief, the person responsible for brushing the child's teeth was asked to brush the child's teeth as usual. Only 7 children used to brush by themselves and they did it as normally they would 
do. All toothbrushes were pre-weighed using a portable electronic balance (FX 300) with 0.01-g precision. After placing the dentifrice, the toothbrush was weighed again, so the amount of toothpaste could be determined. Then, the child had his/her teeth brushed either by the person responsible or by himself/herself as usual. When toothbrushing was completed, all residual dentifrice around his/her mouth and any spit out were collected and placed in $30 \mathrm{~mL}$ of distilled deionized water. The toothbrush was also placed in the same container and shaken until no residual toothpaste was present at the toothbrush (solution 1). Solution 1 was then frozen at $-12^{\circ} \mathrm{C}$ and later transported to the laboratory for fluoride analysis. A sample of the child's toothpaste was also collected for analysis.

\section{Fluoride analysis}

The collected solution (toothbrush residue + child's expectorate) was defrosted at room temperature and completely homogenized. An amount of $0.5 \mathrm{~mL}$ of $2 \mathrm{M} \mathrm{HCl}$ was added to each $0.5 \mathrm{~mL}$ of the collected solution. This mixture was then incubated for 1 hour at $45^{\circ} \mathrm{C}$, under vigorous agitation (1300 rpm) in a Compact Thermomixer (Eppendorf Corp., Germany). After this time, the mixture was neutralized with $1.0 \mathrm{~mL}$ of $1 \mathrm{M} \mathrm{NaOH}$ and $2 \mathrm{~mL}$ of TISAB II were added. The same procedure was applied to the standards. Then, the standards and samples were analyzed in duplicate, using the specific ion electrode (combined F- electrode 96-09 Orion Res. Inc., USA) coupled to a pH/MV metter (Procyon Research Inc., Brazil). Fluoride standards ranged from 4 to 64 ppm F-. The fluoride ingestion from the toothpaste was calculated by subtracting the fluoride in solution from the fluoride content in the toothpaste. Information about daily toothbrushing frequency and weight of each child were used to calculate the ingested $\mathrm{mg} \mathrm{F}^{-} / \mathrm{kg}$ of body weight/day.

\section{Statistical analysis}

The $\mathrm{mV}$ readings produced by the samples and by the fluoride standards were entered into a computer and transformed in ppm using a polynomial equation and the Statview statistical package (SAS Institute, USA, 1995). Regression analysis was done to assess the relationship between age of the children and fluoride intake from toothpastes. All fluoride and children information data were entered into an Excel ${ }^{\mathrm{TM}}$ spreadsheet and analyzed using the EpiInfo 2000 statistical package.

\section{RESULTS}

There were differences in fluoride concentration when comparing different collection sites. There were also day to day fluctuations at the same site. Figure 1 shows $\mathrm{F}^{-}$ concentrations fluctuating during the collection days. Water sample fluoride concentration ranged from 0.58 - 1.52 ppm $\mathrm{F}^{-}$. The mean $\mathrm{F}^{-}$concentration was 0.94 ppm (range 0.781.14).

Fluoride concentration in the toothpastes used by the children ranged from $1,063 \pm 16.31$ to $1,514 \pm 78.8 \mathrm{ppm} \mathrm{F}^{-}$
(Table 1). The mean ( $\pm \mathrm{SD})$ amount of toothpaste placed on each toothbrush was $0.58 \pm 0.20 \mathrm{~g}$.

The mean $( \pm \mathrm{SD})$ age of the children was $2.4 \pm 04$ years and their mean weight was $13.31 \pm 2.89 \mathrm{Kg}$. About $70 \%$ of children in this study began toothbrushing from 6 to 18 months of age, $20 \%$ between 18 and 24 months of age and $12 \%$ in a later age; $69 \%(n=40)$ of the children brush their teeth 3 or more times a day, $22.4 \%(n=13)$ do it twice a day and only $8.6 \%(n=5)$ once a day. No one reported not to brush the teeth of their child.

A total of $89.7 \%(n=52)$ had the habit of swallowing toothpaste during toothbrushing but only $31 \%$ would eat toothpaste in occasions other than during toothbrushing time.

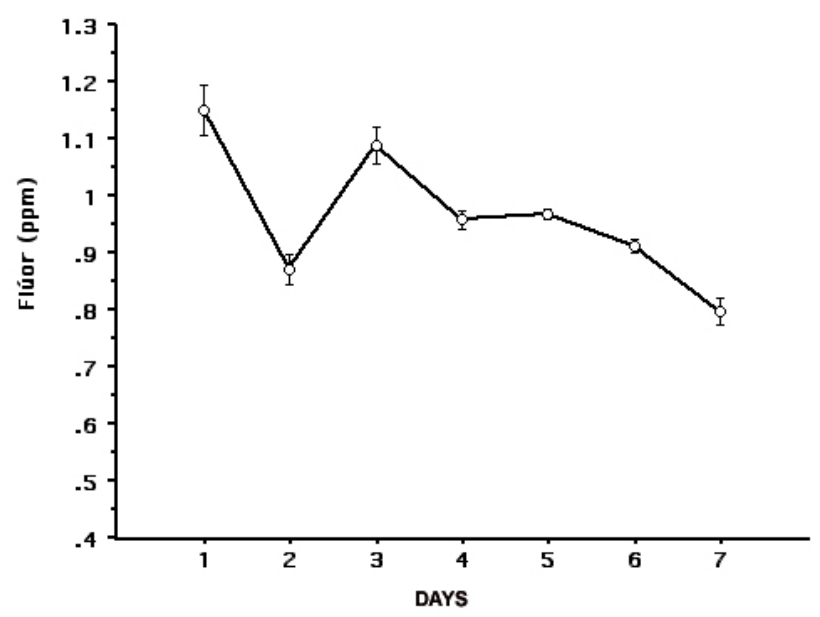

FIGURE 1- Mean fluoride concentration (ppm) in the drinking water of Penedo in 7 different days.

(small bars are the standard error of the mean)

TABLE 1- Mean Fluoride ( $\pm S D$ ) concentration in toothpastes used by children in Penedo, Brazil

\begin{tabular}{lll}
\hline Toothpaste brand & $\mathbf{n}$ & Mean ppm F- \\
\hline Colgate $^{*}$ & 3 & $\begin{array}{l}1,514 \\
(78.8)\end{array}$ \\
& & 1,189 \\
Close up** & 2 & $(7.7)$ \\
& & 1,063 \\
Contente* & 4 & $(16.3)$ \\
& & 1,173 \\
Gessy crystal** & 2 & $(4.2)$ \\
& & 1,460 \\
Sorriso* & & $(75.9)$ \\
& 5 & 1,215 \\
Tandy** & & $(166.5)$ \\
\hline
\end{tabular}

*Samples collected at the nursery school;

** Samples collected in child's home. 
The mean \pm SD of fluoride placed on the toothbrush was $0.711 \pm 0.245 \mathrm{mg}$, from which $0.153 \pm 0.187 \mathrm{mg}$ was expectorated. The estimated mean of $\mathrm{F}^{-}$ingested was $0.558 \pm 0.232 \mathrm{mg} \mathrm{F}^{-}$.

Table 2 shows mean $( \pm \mathrm{SD})$ fluoride ingested from water and fluoridated toothpastes. The F-intake from water corresponds to less than $20 \%$ of the mean daily $\mathrm{F}^{-}$ingested. Toothpaste accounted for $84 \%$ of the daily $\mathrm{F}^{-}$ingested. Only $3.4 \%(n=2)$ of the children did not reach the limit of $0.07 \mathrm{mg}$ $\mathrm{F}^{-} / \mathrm{kg}$ of body weight/day.

There was a positive and significant correlation ( $\mathrm{r}=0.45$, $\mathrm{p}<0.05$ ) between age of the child and $\mathrm{F}^{-}$ingested ( $\mathrm{mg}$ ) from toothpaste per Kilogram of body weight (Figure 2). There was no significant correlation either for males or females when analyzed separately.

\section{DISCUSSION}

In Brazil, the most common sources of fluoride are fluoridated water, toothpaste and professional topical application. However, there are probably regional differences that should be considered. In the South and Southeast regions of Brazil, over $60 \%$ of the population is exposed to fluoridated water, compared to only $6.85 \%$ in the Northeast region and $13 \%$ in the North region ${ }^{8}$. There are reports that the water fluoridation system is not well controlled in other cities of Brazil. For example, the fluoride concentration in Bauru, state of Sao Paulo, ranged from 0.01 to $1.3 \mathrm{ppm}^{9,4}$.

In Penedo, fluoride was above the recommended level of $0.7 \mathrm{ppm} \mathrm{F}^{-}$in many of the water samples. On the other hand, the contribution of fluoridated drinking water to $\mathrm{F}^{-}$ ingestion was only $0.02 \mathrm{mg} \mathrm{F}$-/ Kg body weight/day, which is well below the theoretical threshold of $0.07 \mathrm{mg} \mathrm{F}^{-} / \mathrm{Kg}$ body weight/day and this daily dosage poses little risk for dental fluorosis. This intake from water reflects a calculation using the mean fluoride concentration in water: $0.94 \mathrm{ppm}$. Since a fluctuation occurred, a range in $\mathrm{F}^{-}$ingestion from water can be expected. The high fluoride concentration in the drinking water of Penedo may occur in other parts of Brazil and is probably related to the lack of automatic dosage devices and fluoride specific electrodes to monitor the fluoride concentration in the water and trained personnel ${ }^{9}$. Water fluoridation control is expected to be improved after implementing new health governmental programs ${ }^{22}$.

In Chile, Villa, et al. ${ }^{25}$ (1998) suggested that there are no additional benefits from $\mathrm{F}^{-}$concentrations greater than 0.53 ppm in the drinking water. Moreover, in the United States, additional caries reduction obtained with a fluoride concentration in water higher than $0.7 \mathrm{ppm}$ appears to be negligible or non-existent ${ }^{10}$. It is reasonable to maintain the water fluoride concentration at 0.7 ppm in Penedo, since dental caries is still a problem in that area and there is no guarantee about utilization of fluoridated toothpastes by the children ${ }^{22}$. In addition, there is evidence that dental fluorosis can be reduced by $50 \%$ without changes in the fluoride level in water ${ }^{20}$.

The Contente and Gessy Cristal toothpastes claim to have a fluoride concentration of $1,450 \mathrm{ppm} \mathrm{F}^{-}$, yet our analysis detected only 1,063 $\mathrm{ppm} \mathrm{F}^{-}$and 1,163 $\mathrm{ppm} \mathrm{F}^{-}$, respectively. Since these toothpastes have calcium carbonate as the abrasive component, despite the treatment with hydrochloric acid, fluoride may have combined with calcium and may not have been detected by our analysis. However, the toothpastes Colgate and Sorriso showed a fluoride concentration within 5\% of the labeled fluoride concentration in spite of having similar abrasive and fluoride compound as the others. Similar results have been shown in toothpastes from countries with non-established market economies ${ }^{24}$. Thus, it appears that the formulation of these toothpastes needs improvement.

In Brazil, low socioeconomic status groups seldom use fluoridated toothpaste but this is not the case in Penedo ${ }^{26}$.

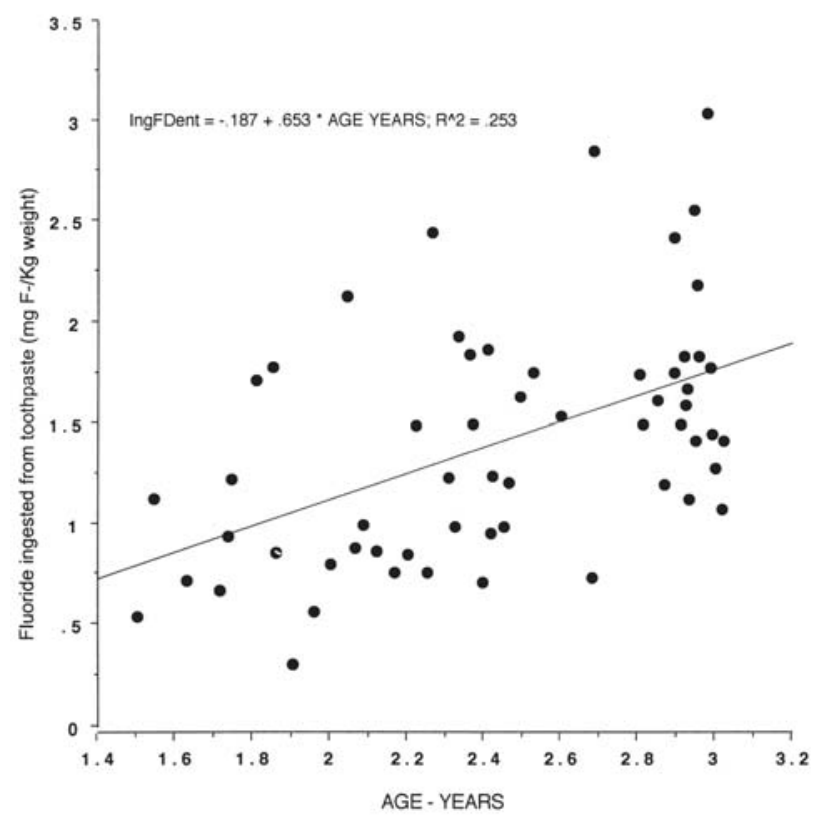

FIGURE 2- Relationship between age of children and fluoride ingestion

TABLE 2- Mean ( $\pm S D$ ) ingested fluoride from water and dentifrice (mg F- $/ \mathrm{Kg}$ Body Weight/ day) by children living in Penedo, Brazil

\begin{tabular}{lll} 
F- Source & Dose $(\mathbf{m g}$ F- $/$ Kg Body Weight/ day) & $\%$ \\
\hline Water & $0.021 \quad(0.012)$ & 16.4 \\
Toothpaste & $0.107(0.045)$ & 83.6 \\
Total & $0.128(0.046)$ & 100.0 \\
\hline
\end{tabular}


The preventive dentistry program emphasizes the use of fluoridated toothpaste by young children. Brushing the teeth 3 times a day at this age is unusual. However, in Penedo's nursery schools, it is mandatory for each child to have their teeth brushed after their first and the last meal before going home. Parents are also encouraged to avoid their child going to bed with dirty teeth. Even though it is desirable to establish the habit of toothbrushing earlier in life, these children are using toothpastes with high fluoride concentration, not recommended for this age group. However, unlike other countries or even other Brazilian regions, where the so-called low dosage (400-550 ppm $\mathrm{F}^{-}$) children's toothpastes are available ${ }^{20}$; low fluoride toothpastes are not easily available in Penedo. Seventy percent of the children brushed their teeth 3 or more times per day and 89\% enjoyed eating toothpaste, therefore it can be assumed that the risk for developing dental fluorosis is high. Two facts also add to the high intake of fluoride by these children: a) the cheapest toothpastes found in the Brazilian market have a fluoride concentration between 1,450 and $1,500 \mathrm{ppm}$, and b) the recommendation to fill the toothbrush bristles with toothpaste is stated in the health program in Penedo. Thus, the solution to reduce the fluoride intake from toothpaste could be to provide a low dosage children's toothpaste or by placing smaller amounts of toothpaste on the toothbrush when using a normal but lower concentration of 1,000-1,100 ppm $\mathrm{F}^{-}$toothpaste and by discouraging the habit of ingesting toothpaste. In Australia, Riordan ${ }^{20}$ (2002) showed that reducing the use of fluoride supplements and promoting the use of low fluoride toothpastes reduced dental fluorosis.

Even though some studies reported that fluoride ingestion during toothbrushing is reduced with age, we found the opposite ${ }^{18,19}$. This could be due to the age of the children in this study. Other studies compared toothpaste ingestion in 3- to 7-year-old children while in this study the children are younger and the difference in age are is only some months ${ }^{19}$. Another possibility might be that during this period and up to certain age, toothpaste ingestion increases and then later diminishes. Levy et al. ${ }^{14}$ (2001) observed that fluoride intake increases from $12-20$ months and decreases with increasing mother's age in a three-way interaction. We could not evaluate this three-way interaction in this study.

Additional fluoride intake from food was not evaluated in this study. As food is prepared with drinking water and the food itself may contain some fluoride, the total fluoride ingestion may be even higher than observed. It is estimated that a fluoride intake of $1.0 \mathrm{mg}$ from toothpaste plus $0.5 \mathrm{mg}$ $\mathrm{F}^{-}$from diet may produce a total fluoride intake of $0.107 \mathrm{mg}$ $\mathrm{F}^{-} / \mathrm{kg} \mathrm{bw}^{13}$. Our findings are very similar to those found in Bauru: $0.130 \mathrm{mg} \mathrm{F}^{-} / \mathrm{kg}$ bw for total $\mathrm{F}^{-}$intake${ }^{1}$. In the Bauru study, fluoridated toothpaste alone contributed with 0.106 $\mathrm{mg} \mathrm{F}^{-} / \mathrm{kg}$ bw, whereas in our study this value was $0.107 \mathrm{mg}$ $\mathrm{F}^{-} / \mathrm{kg}$ bw. Although brushing frequency might be overestimated in our study due to daily variations in brushing frequencies, the $\mathrm{F}^{-}$intake is high and needs to be considered by public health authorities. A survey of dental caries and fluorosis prevalence is being conducted to establish the real situation in this area.

\section{CONCLUSIONS}

Children in Penedo are at risk for developing dental fluorosis due to high $\mathrm{F}^{-}$intake from fluoridated toothpastes. Water fluoridation showed low contribution to the total $\mathrm{F}^{-}$ intake. However, high water $\mathrm{F}^{-}$concentrations in the water indicate the need of surveillance of the artificial water fluoridation system.

\section{REFERENCES}

1- Almeida BS, Cardoso VES, Buzalaf MAR. Fluoride ingestion from toothpaste and diet in 1-3-year-old Brazilian children. Community Dent Oral Epidemiol (in press).

2- Brasil. Ministério da Saúde. Secretaria de Atenção à Saúde. Departamento de Atenção Básica. Coordenação Nacional de Saúde Bucal. Projeto SB Brasil 2003: Condições de saúde bucal da população brasileira 2002-2003. Resultados principais. Brasília. 2004. 51 p.

3- Burt BA. The changing patterns of systemic fluoride intake. J Dental Res. 1992; 71(5):1228-37.

4- Buzalaf MAR, Granjeiro JM, Damante CA, Ornelas F. Fluctuations in public water fluoride level in Bauru, Brazil. J Public Health Dent. 2002; 62(3):173-6.

5- Carvalho JC, Nieuwenhuysen JP, D'Hoore W. The decline in dental caries among Belgian children between 1983 and 1998. Community Dent Oral Epidemiol. 2001; 29(1): 55- 61.

6- Clark DC. Trends in prevalence of dental fluorosis in North America. Community Dent Oral Epidemiol. 1994; 22(3):148-52.

7- Evans RW, Darvell, BW. (1995): Refining the estimate of the critical period for susceptibility to enamel fluorosis in human maxillary central. J Public Health Dent. 1995; 55(4):238-49.

8- Ferreira HCG, Gomes AMM, Silva KRCS, Rodrigues CRMD, Gomes AA. Avaliação do teor de flúor na água de abastecimento público do município de Vitória - ES. Rev da APCD. 1999; 53:455-9.

9- Heintze SD, Bastos JRM, Bastos R. Urinary fluoride levels and prevalence of dental fluorosis in three Brazilian cities with different fluoride concentration in the drinking water. Community Dent Oral Epidemiol. 1998; 26(5):316-23.

10- Heller KH, Eklund SA, Burt BA. Dental caries and dental fluorosis at varying water fluoride concentrations. J Public Health Dent . 1997; 57:136 - 43 .

11 - Instituto Brasileiro de Geografia e Estatística (IBGE) Indicadores Sociais do Brasil. (2002). Available at: http://www.ibge.gov.br/ população/ indicadoressociaismínimos.

12- Instituto Brasileiro de Meteorologia (2003): available at http:// www.inmet.gov.br/produtos/.

13- Levy SM, Kohout FJ, Guha-Chowdury N, Kiritsy MC, Heilman JR, Wefel JS. Infants' fluoride intake from drinking water alone, and from water added to formula, beverages and food. J Dent Res. 1995; 74(7):1399-407. 
14- Levy SM, Warren JJ, Davis CS, Kirchner HL, Kanellis MJ, Wefel JS. Patterns of fluoride intake from birth to 36 months. J Public Health Dent . 2001; 61(2):70-7.

15- Lima YBO, CURY JA Fluoride ingestion by children from water and dentifrice. Rev Saúde Pública. 2001; 35, 576 - 81.

16- Marthaler TM, O’Mullane DM, Vrbic V. The prevalence of dental caries in Europe 1990-1995. Caries Res. 1996; 30(4):237-55.

17- Mascarenhas AK. Risk factors for dental fluorosis: a review of the recent literature. Pediatr Dent. 2000; 22(4):269-77.

18- Murakami T, Narita N, Nakagaki H, Shibata T, Robinson C. Fluoride intake in Japanese children aged 3-5 years by duplicate-diet technique. Caries Res. 2002; 36(6):386-90.

19- Naccache H, Simard PL, Trahan L, Brodeur JM, Demers M, Lachapelle D, Bernard M. Factors affecting the ingestion of fluoride dentifrice by children. J Public Health Dent. 1992; 52(4):222 - 6.

20- Riordan PJ. Dental fluorosis decline after changes to supplement and toothpaste regimens. Community Dent Oral Epidemiol. 2002; $30(3): 233-40$

21- Rojas-Sanchez F, Drake KM, Eckert GJ, Stookey GK, Dunipace AJ. Fluoride intake from foods, beverages and dentifrice by young children in communities with negligibly and optimally fluoridated water: a pilot study. Community Dent Oral Epidemiol. 1999; 27(4): $288-97$.

22- Secretaria Executiva de Saúde. Coordenação de Gestão Políticas de Saúde. Manual de Orientação para implantação dos CEOS e LRPDS. Projeto de Assistência em Saúde Bucal - PROASB. Alagoas. 2005.

23- Szpunar SM Burt BA. Evaluation of appropriate use of dietary fluoride supplements in the US. Community Dent Oral Epidemiol. 1992; 20(3):148-54.

24- van Loveren C, Moorer WR, Buijs MJ, van Palenstein Helderman $\mathrm{WH}$. Total and free fluoride in toothpastes from some non-established market economy countries. Caries Res. 2005; 39: 224-30.

25- Villa AE, Guerrero S, Vilalobos J. Estimation of optimal concentration fluoride in drinking water under conditions prevailing in Chile. Community Dent Oral Epidemiol. 1998; 26(4):249 - 55.

26- Witt MC.Pattern of caries experience in a 12-year-old Brazilian population related to socioeconomic background. Acta Odontol Scand. 1992; 50(1):25-30. 